\title{
Immobilization of amylase using chitosan beads as support
}

Imobilização de amilase utilizando esferas de quitosana como suporte

\author{
T. S. de Oliveira1; C. M. S. Almeida ${ }^{2}$; J. N. de Jesus²; R. D. M. Ferreira ${ }^{2}$; V. S. \\ Varandas $^{2}$; P. A. W. Cavalcante ${ }^{1}$; D. F. Coêlho ${ }^{2}$; J. R. da S. Rodrigues ${ }^{2}$; R. R. de \\ Souza ${ }^{1,2}$
}

\begin{abstract}
${ }^{I}$ Programa de Pós-Graduação em Engenharia Química, Laboratório de Biotecnologia Ambiental (LABAM), Departamento de Engenharia Químical/Laboratório de Bioquímica Industrial/ Universidade Federal de Sergipe, 49100-000, São Cristóvão-Sergipe, Brasil.

${ }^{2}$ Departamento de Engenharia Química, Laboratório de Biotecnologia Ambiental, Universidade Federal de Sergipe, 49100-000, São Cristóvão-Sergipe, Brasil.
\end{abstract}

*jregrodrigues@gmail.com

(Recebido em 30 de julho de 2017; aceito em 11 de novembro de 2017)

\begin{abstract}
Amylases are hydrolases that are prominent, compared to other enzymes, accounting for $65 \%$ of the world's market. They can be applied to any processes that require partial or complete hydrolysis of starch, such as: glucose production, the paper industry, brewing industry, food industry, among others. The use of enzymes in the industry brings great advantages, such as: a lower energy consumption; selectivity for the substrate; high activity and, in most cases, low production cost. However, it is still a costly catalytic route option, and it is necessary to use immobilization processes so that no further costs are generated in its recovery after the reaction. This work aimed to produce chitosan beads for use in the immobilization of amylase from a nonpurified source. The enzymatic broth volume evaluated was 7 and $10 \mathrm{~mL}$, with the highest rate of immobilization (36.04\%) and recovered activity (12.36\%) achieved using $7 \mathrm{~mL}$ of enzymatic broth. In the evaluation of the number of spheres used for immobilization, 6, 10 and 14 units were evaluated. It was found that the smallest number of spheres was sufficient to immobilize $54.71 \%$ of the enzymes. However, the recovery activity was the lowest $(6.77 \%)$. Immobilization by covalent bonding presented better immobilization result compared to other immobilizations $(54.71 \%)$, despite the lower result for recovery of activity $(6.77 \%)$.

Keywords: immobilization, amylase, chitosan
\end{abstract}

Amilases são hidrolases consideradas proeminentes frente a outras enzimas, representando $65 \%$ do mercado mundial. Elas possuem aplicações em todos os processos que necessitam da hidrólise parcial ou completa do amido, tais como a produção de glicose, nas indústrias de papel, na indústria cervejeira, na indústria alimentícia, entre outros. $\mathrm{O}$ uso de enzimas na indústria traz grandes vantagens, tais como: um menor gasto energético; seletividade acentuada para o substrato; alta atividade e, na maioria dos casos, custo baixo para produção. No entanto, ainda é uma opção de rota catalítica dispendiosa, sendo necessário utilizar processos de imobilização dessa enzima, para que não sejam gerados custos adicionais na sua recuperação após a reação. Este trabalho teve o objetivo de imobilizar a amilase presente em caldo não purificado, por meio de esferas de quitosana. O volume de caldo bruto foi avaliado em 7 e $10 \mathrm{~mL}$, sendo a maior taxa de imobilização $(36,04 \%)$, e de atividade recuperada $(12,36 \%$ ) alcançadas na utilização de $7 \mathrm{~mL}$ de caldo enzimático. $\mathrm{Na}$ avaliação do número de esferas utilizadas para imobilização, foram avaliadas 6, 10 e 14 unidades. Verificouse que o menor número de esferas era suficiente para imobilizar 54,71\% das enzimas. No entanto, a atividade de recuperação foi a mais baixa $(6,77 \%)$. A imobilização por ligação covalente apresentou melhor resultado de imobilização frente às outras imobilizações $(54,71 \%)$, apesar do menor resultado para a recuperação de atividade $(6,77 \%)$.

Palavras-chave: imobilização, amilase, quitosana

\section{INTRODUCTION}

Enzymes are proteins with catalytic characteristics, thus, they are natural compounds, which have capacity of intensify the speed of chemical reactions, therefore increasing the efficiency of metabolism in living organisms [1]. They can be classified into six classes that are: 
Oxidoreductases; Transferases; Hydrolases; Lyases; Isomerases and Ligases - depending on the kind of reaction to be catalysed [2]. Enzymes can be obtained from animal, vegetable and microbial sources, where the microbial route is the most used for biotechnological application due its lower production costs, the easibly of purification (extracellular), the high specificity, the independence of seasonality and the possibility of production in Large scale [3, 4].

Among the various enzymes used in industrial processes, amylolytic enzymes, called amylases, are important hydrolases that accounts for $65 \%$ of the world market $[5,6]$. They have applications in processes that require partial or complete hydrolysis of starch [7], such as in paper industries to protect it from mechanical damage and improvement of final finishing; In the brewing industry to produce light beers; in the food industry to eliminate turbidity produced by starches, among other applications in the most diverse branches $[8,9]$.

Due to the wide range of its benefits, when compared to conventional chemical catalysts, the use of enzymes in industrial processes has increased considerably [10]. Benefits such as: reaction in mild temperatures, using less energy in the process; selectivity to the substrate, which directly interferes with greater efficiency in the use of the raw material; high activity and, in most cases, low cost for production, making biocatalysis the most advantageous option [2,11].

Aires-Barros (2002) [11] warns about the difficulty in recovering the enzyme from the reaction medium, especially when using water as solvent, because the catalysis becomes homogeneous, which prevents catalyst removal and its subsequent reuse. However, the same author suggests as a solution to this problem, the enzyme immobilization in supports of low solubility that transforms homogeneous catalysis into heterogeneous, thus allowing enzyme recovery from the reaction medium and enabling its reuse, as well as increasing stabilization and, consequently, reducing the costs of the process.

Dalla-Vecchia et al. (2004) [12] also highlight the need to protect the enzymes from the interactions with the solvents, under the risk of being inactivated, mentioning the immobilization techniques as a solution for such a problem.

Immobilization is a process in which the enzyme is confined or bonded to a region of an insoluble support that retains catalytic activity. Such technique improves the properties of the biocatalyst by increasing the stability and rigidity of the structure, causing hyperhydrophilic microenvironments, which may protect the biocatalyst, and consequently reduce the inhibitions caused by irreversible / reversible inhibitors. However, one of the essential factors that must be considered when using a specific immobilization system is the type of interaction between the support and the biocatalyst, which can directly influence its stability and on the kinetic effects of catalysis [13].

Among available immobilization methods, covalent bonding is one of the most studied methods because the stability effects provided by the enzyme-support complex. The high stability is mostly due to multicovalent bonds, which produce rigid structures and thus less susceptible to conformational changes [14]. Such a method is based on binding between amino acid patches present on enzyme surface and support's reactive groups [15].

However, this type of bonding requires more complex procedures than the others. As is the case of the activation of the binder group, a process of great importance because it allows establishing a kind of organic bridge between the support and the protein, allowing the formation of the enzymesupport complex. Activation of the support is intended to reduce the risk of reducing the catalytic activity of the enzyme. Such importance is given by the difficulty of finding carriers that already contain these reactive groups and promote the direct coupling with the enzyme without interfering in its catalytic center. The most commonly used activation reactions are amide bond formation, diazotization and alkylation. Being the glutaraldéido, the activating agent more used, mainly in organic supports, like the chitosan and the chitin $[16,17]$

Among the different organic substrates used in the immobilization of enzymes, chitosan stands out. Chitosan ( $\beta$ (1-4) -2-amino-2-deoxy-D-glucose) was evaluated by Oliveira and Vieira (2006) [18] as an appropriate support for enzymes due to the large presence of amino and hydroxyl groups available in their structure.

This work aims to study immobilization of amylase present in amylase-enriched broth, obtained through submerged fermentation, in chitosan beads. The influence of the parameters - volume of crude enzyme broth, number of beads, use of the activation agent and type of immobilization adopted - also evaluated in the immobilization yield. 


\section{MATERIAL AND METHODS}

\subsection{Enzymatic Broth}

The enzymatic broth was obtain by submerged fermentation using as substrate manipueira (wastewater produced during cassava flour production). The microorganism used was a bacteria (rod-shaped, Gram positive) called TP02, isolated from the manipueira and belonging to the strain bank of the Laboratory of Environmental Biotechnology (LABAM-UFS), which is in the taxonomic identification phase [19].

The fermentation was performed at $200 \mathrm{rpm}$, temperature $30^{\circ} \mathrm{C}$ and $\mathrm{pH}$ 7. After 144 hours of fermentation, the medium was centrifuged at for 30 minutes and the supernatant used as enzymatic broth.

\subsection{Chitosan Beads}

To produce support beads, $1 \mathrm{~g}$ of chitosan was weighed and diluted in $30 \mathrm{~mL}$ of a $5 \%(\mathrm{v} / \mathrm{v})$ acetic acid solution. The obtained solution were dripped and with constant stirring, to a basic solution of $1 \mathrm{M} \mathrm{NaOH}$. A peristaltic pump equipped with a $5 \mathrm{~mm}$ diameter nozzle was used to control beads size. The beads obtained were kept in a $1 \mathrm{M} \mathrm{NaOH}$ solution for a period of 24 hours. After this time, they were washed and stored, under refrigeration, in a beaker with distilled water [17].

\subsection{Beads Activation}

Chitosan beads were active by mixing $1 \mathrm{~g}$ of beads in a beaker to $3 \%(\mathrm{v} / \mathrm{v})$ glutaraldehyde solution in an orbital shaker at room temperature and $120 \mathrm{rpm}$ for 24 hours. After activation, beads were washed with distilled water, filtered using a vacuum pump and stored in a refrigerator until its use [17].

\subsection{Amylase Immobilization}

Activated beads were filtered and washed with a pH 5.5, 0.1M sodium acetate buffer. Then, ten activated beads were transferred to a beaker containing $10 \mathrm{~mL}$ of enzyme broth. The beaker was placed in orbital shaker (Certomart ${ }^{\circledR}$ BS-1) at room temperature and $120 \mathrm{rpm}$ for 24 hours. Beads with immobilised amylase were kept in a $0.1 \mathrm{M}$ sodium acetate and $\mathrm{pH} 5.5$ under refrigeration, in order to preserve the enzymes activity.

Amylase immobilization efficiency is quantified as immobilization yield, which calculates how much of the activity was transferred from the enzymatic broth to the chitosan support (see Equation 1). The immobilization analysis is also quantified in relation to the recovered activity, which consists of the ratio between the activity of a sphere and the activity extracted from the crude broth, as shown in Equation 2.

$$
\begin{aligned}
& \text { Immobilisation Yield (\%) }=\frac{A_{\text {broth }}-A_{\text {supernatant }}}{A_{\text {broth }}} * 100 \\
& \text { Recovered Activity }(\%)=\frac{A_{\text {beads }}}{A_{\text {broth }}-A_{\text {supernatant }}} * 100
\end{aligned}
$$

\subsection{Enzymatic Activity Assay}

The amylase activity was calculated by analysing the reducing sugar released through hydrolysis of the starch using the 3,5-Dinitrosalicylic acid (DNS) method, as described by Miller (1959) [20].

The activity in liquid sample were analysed by mixing $0.5 \mathrm{~mL}$ of a 50 -fold diluted (using a 0.1 $\mathrm{mol} / \mathrm{L}$ sodium acetate buffer and $\mathrm{pH} 5.5)$ enzymatic sample to $0.5 \mathrm{~mL}$ of $0.5 \%(\mathrm{~m} / \mathrm{v})$ soluble starch solution, also prepared using the buffer above mentioned, in a test tube. The tube was incubated for 10 minutes at $50{ }^{\circ} \mathrm{C}$. After incubation, $1 \mathrm{~mL}$ of DNS reagent was added. The mixture was heated in a boiling bath for 5 minutes, cooled, diluted in $10 \mathrm{~mL}$ of distilled water and homogenized. After 
homogenisation, the absorbance was read in a spectrophotometer at $540 \mathrm{~nm}$ against a blank prepared as described above, but replacing the volume of the reaction mixture $(1 \mathrm{~mL})$ with acetate buffer.

The method to analyse amylase activity for the biocatalyst (beads with immobilised amylase) differs from the above mentioned only due the $0.5 \mathrm{~mL}$ of enzymatic sample replacement by one biocatalyst bead. The bead was not withdrawn from the tube at any stage.

One unit of enzyme activity $\left(U \cdot m L^{-1}\right)$ was defined as the amount of enzyme required to release $1 \mu \mathrm{mol}$ of reducing sugar per minute, which can be expressed by Equation 3:

$$
\operatorname{Activity}\left(\frac{\mathrm{U}}{\mathrm{mL}}\right)=\frac{\mathrm{Abs} * \mathrm{~m} * \mathrm{~F}_{\mathrm{D}}}{\mathrm{t} * \mathrm{~V}}
$$

Where:

Abs is the absorbance measured in the spectrophotometer; $m$ is the slope for the DNS' method calibration curve $\left(13,348 \frac{\mu \mathrm{mol}}{\mathrm{Abs} * \mathrm{~mL}}\right) ; \mathrm{F}_{\mathrm{D}}$ is the dilution factor; $\mathrm{t}(10 \mathrm{~min})$ is the incubation time; and $\mathrm{V}(\mathrm{mL})$ is the volume of sample containing the enzyme.

\section{RESULTS AND DISCUSSION}

\subsection{Influence of crude broth volume in the immobilization}

To study the influence of crude broth volume in the immobilization of amylase, different volumes of enzymatic broth were added to ten chitosan beads and the immobilization processes followed as described previously. Table 1 shows the enzymatic activity, immobilization yield and recovered activity obtained for the crude broth, biocatalyst and supernatant for each assay with different crude broth volumes.

Table 1: Influence of crude broth on immobilization yield and recovered activity

\begin{tabular}{lccc}
\hline \multicolumn{1}{c}{ Sample } & $\begin{array}{c}\text { Enzymatic Activity } \\
(\mathbf{U} / \mathbf{m L})\end{array}$ & $\begin{array}{c}\text { Immobilization } \\
(\boldsymbol{\%})\end{array}$ & $\begin{array}{c}\text { Recovered } \\
\text { Activity (\%) }\end{array}$ \\
\hline Enzymatic & 52,40 & - & - \\
$\begin{array}{l}\text { Broth } \\
\text { Biocatalyst }\end{array}$ & 2,34 & & \\
Supernatant $^{\mathbf{a}}$ & 33,41 & 36,04 & 12,36 \\
Biocatalyst $^{\mathbf{b}}$ & 1,49 & & \\
Supernatant $^{\mathbf{b}}$ & 38,35 & 26,58 & 10,72 \\
\hline
\end{tabular}

a: $7 \mathrm{~mL}$ volume of crude broth was used on immobilization.

b: $10 \mathrm{~mL}$ volume of crude broth was used on immobilization.

The best immobilization results and recovered activity were obtained by the assay using the lowest volume of crude broth ( $36.04 \%$ and $12.36 \%$, respectively). These results contradict the experiments of Tripathi (2007) [21] and Kumari (2011) [22], where an increase in the volume of enzymatic broth resulted in an increase of specific immobilization. Differences can possibly be a result of the enzyme source used, since this study chose to use a non-purified fermented broth and it might contain several interfering substances. These interferents can act by binding to the chitosan support and thus preventing binding between the support and the enzyme even in the presence of an activator. Therefore, a larger volume of enzyme broth, which proportionally contain a greater amount of interferents, would cause both the deactivation of the enzymes and the occupation of sites originally intended for enzymes.

\subsection{Influence of the number of chitosan beads in the immobilization}

By fixing the volume of crude broth to $7 \mathrm{~mL}$, it was possible to vary the amount of chitosan beads in 6,10 and 14 units to evaluate their effect on immobilization. Table 2 shows the results. 
Table 2: Influence of number of chitosan beads on immobilization yield and on recovered activity

\begin{tabular}{cccc}
\hline Sample & $\begin{array}{c}\text { Enzymatic } \\
\text { Activity (U / mL) }\end{array}$ & Immobilization (\%) & $\begin{array}{c}\text { Recovered Activity } \\
\text { (\%) }\end{array}$ \\
\hline Biocatalyst $^{\text {a }}$ & 1,94 & 54,71 & 6,77 \\
Supernatant $^{\text {a }}$ & 23,73 & & \\
Biocatalyst $^{\text {b }}$ & 2,34 & 36,04 & 12,36 \\
Supernatant $^{\text {b }}$ & 33,44 & & 13,11 \\
Biocatalyst $^{\text {c }}$ & 2,49 & 36,24 & \\
Supernatant $^{\text {c }}$ & 33,41 & & \\
\hline
\end{tabular}

a: 6 beads were used in immobilization.

b: 10 beads were used in immobilization.

c: 14 beads were used in immobilization.

According to Table 2, the highest immobilization yield occurred in the assay with the lowest number of chitosan beads (54.71\%), again counteracting the expected result. This means that, even though it is a covalent binding immobilization process, initial diffusion effects may have restricted the mobility of the enzyme present in the broth due to the excessive amount of support causing it to lose accessibility to the substrate (this explains the low recovered activity) and the support (low immobilization yield).

\subsection{Influence of the active agent in the immobilization}

Using the best conditions established in the previous experiments $-7 \mathrm{~mL}$ crude broth volume and 6 chitosan beads - the activating agent was varied at immobilization, the first assay being an immobilization by covalent attachment using glutaraldehyde; the second test is a simple physical adsorption; and the third a combination of adsorption followed by activation. Table 3 shows the results obtained.

Table 3: Influence of the activating agent in the immobilization yield and on the recovered activity

\begin{tabular}{cccc}
\hline Sample & $\begin{array}{c}\text { Enzymatic Activity } \\
(\mathbf{U} / \mathbf{~ m L})\end{array}$ & $\begin{array}{c}\text { Immobilization } \\
(\%)\end{array}$ & $\begin{array}{c}\text { Recovered } \\
\text { Activity (\%) }\end{array}$ \\
\hline Biocatalyst $^{\text {a }}$ & 1,94 & 54,71 & 6,77 \\
Supernatant $^{\text {a }}$ & 23,73 & & \\
Biocatalyst $^{\mathbf{b}}$ & 1,02 & 19,78 & 9,80 \\
Supernatant $^{\mathbf{b}}$ & 42,03 & & \\
Biocatalyst $^{\mathbf{c}}$ & 1,76 & 31,04 & 10,85 \\
Supernatant $^{\mathbf{c}}$ & 36,13 & \\
\hline
\end{tabular}

a: Immobilization with the use of glutaraldehyde.

b: Immobilization without the use of glutaraldehyde.

c: Two immobilizations: with and without glutaraldehyde.

The immobilization that did not use the activating agent was the one with the lowest immobilization yield $19.78 \%$. According to Bon et al (2008) [16], this low yield was expected, since in this case the enzyme was attached to the support through ionic bonds, which have low binding strength characteristics. In addition, it is known that chitosan presents low porosity, which hinders the immobilization process by adsorption.

Pereira et al. (2001) [23] presented similar results for the adsorption immobilization of the lipase enzyme in chitosan, with immobilization yield of $17 \%$. Therefore, in spite of the simplicity and small cost of immobilization through ionic bonds / physical adsorption, it has a low capacity to make connections between the enzyme and the support, requiring a high concentration of enzymes in order for the yield to be satisfactory. In addition, detachment of the enzyme from the support may occur, thus generating a loss of activity of the biocatalyst.

With the intention of filling the empty sites of the biocatalyst, the combination of the two types of immobilization was tested: by weak and covalent bonds, in the same experiment. But unlike 
expected, this process did not show an increase in yield when compared to the experiment that only used strong bonds. Its value is superior only to the process that used ionic / adsorption bonds.

This result can be explained by the way the experiment was performed. At the first immobilization, that is, when the enzymes were bound to the support by weak bonds, not all sites were occupied by enzymes. A portion of them were occupied by inhibitors, as the substrate resulting from the fermentation process. Thus, when the activation of the already immobilized sphere was carried out, the glutaraldehyde field of action was restricted to the free sites, resulting in a reduced immobilization capacity by covalent bonding, resulting in a lower immobilization efficiency.

\section{CONCLUSION}

The immobilization of amylase showed good results, with the highest rate of immobilization $(54.71 \%)$ obtained when using six chitosan beads, $7 \mathrm{~mL}$ of crude broth and glutaraldehyde as the activating agent. The adjustment of parameters, crude broth volume and number of beads provided greater success in the formation of covalent bonds between the enzyme and the biocatalyst, using a smaller amount of biocatalyst, which made the use of chitosan as support in the immobilization by covalent attachment an advantageous method. The results confirm that the uniformity in porosity of chitosan microspheres is very important.

However, such conditions resulted in a lower activity rate recovered $(6,77 \%)$. This suggests that the immobilization is based on the partial entrapment of protein molecules into pores of chitosan generated in the course of covalent binding

\section{REFERENCES}

1. Meireles A, Borges A, Giaoris E, Simões M. The Current Knowlegde on the Application of Anti-biofilm Enzymes in the Food Industry. Food Res Int. 2016 Jun;86:140-146, doi:10.1016/j.foodres.2016.06.006

2. Orlandeli CR, Specian V, Felber CA, Pamplhile AJ. Enzimas de Interesse Industrial: Produção por Fungos e Aplicações. SaBios. 2012 Set/Dez;7(3):97-109.

3. Pandey A, Selvakumar P, Soccol CR, Nigam P. Enzyme Technology. 1 ed. New Delhi: Asiatech Publishers; 2005. 760 p.

4. Fernandes MLM. Produção de lípases por fermentação no estado sólido e sua utilização em biocatálise. [Tese] Curitiba-PR : Universidade Federal do Paraná; 2007. 120 p.

5. Van der Maarel MJ, van der veen B; Uitdehaag JCM, Leemhuis H, Dijkhuizen L. Properties and applications of starch converting enzymes of alpha amylase family. J Biotechnol. 2002 Mar;94(2):137155, doi:10.1016/S0168-1656(01)00407-2

6. Balkan B, Ertan F. Production of $\alpha$-amylase from Penicillium chrysogenum under solid state fermentation by using some agriculture by product. Food Technol Biotech. 2007 Nov;45(4):439-442.

7. Souza PM, Magalhães PO. Application of microbial $\alpha$-amylase in industry - A review. Braz J Microbiol. 2010;41(4):850-861, doi:10.1590/S1517-83822010000400004

8. Norouzian D, Akbarzadeh A, Scharer J, Young MM. Fungal glucoamylases. Braz J Chem Eng. 2006;24:80-85, doi:10.1016/j.biotechadv.2005.06.003

9. Oliveira AN, Flor NS, Oliveira LA. Influência do pH e temperatura sobre a atividade amilolítica de rizóbios isolados de solos da Amazônia. Acta Amaz. Manaus 2010 Jan;40(2):401-404, doi:10.1590/S0044-59672010000200019

10. Messias M, Costa B, Lima GMV, Giese CE, Dekker HFR, Barbosa MA. Lipases Microbianas: Produção, Propriedades e Aplicações Biotecnológicas, Semina: Tech Ex. Londrina. 2011;32(2): $\alpha 3-234$, doi:10.5433/1679-0375

11. Aires-Barros MR. Biocatálise em solvente orgânico; Boletim de biotecnologia, Lisboa; 2002. 19 p.

12. Dalla-vecchia R, Nascimento MG, Soldi V. Aplicações sintéticas de lipases imobilizadas em polímeros. Quim Nova. 2004;27(4):623-630, doi:10.1590/S0100-40422004000400017

13. Sebrão D, Silva VDS, Nascimento MG, Moreira MA. Imobilização de lipases em filme de caseinato de sódio/glicerol: aplicação na síntese de ésteres. Quim Nova. 2007 Out;30(5):1182-1187, doi:10.1590/S0100-40422007000500025

14. Abreu L, Fernandez-Lafuente R, Rodrigues RC, Volpato G, Ayub MAZ. Efficient purificationimmobilization of an organic solvent-tolerant lipase from Staphylococcus warneri EX17 on porous styrene-divinylbenzene beads. J Mol Cata B-Enzym. 2014 Jan;99:51-55, doi:10.1016/j.molcatb.2013.10.018 
15. Cabral JMS, Aires-Barros MR, Gama M. Engenharia Enzimática. Lisboa-Porto-Portugal: Editora LidelEdições Técnicas Ltda; 2003.

16. Bon EPS, Ferrara MA, Corvo ML. Enzimas em biotecnologia: Produção, Aplicações e Mercado. $1^{\mathrm{a}}$ ed. Rio de Janeiro: Editora Interciência; 2008. 506 p.

17. Cruz JA. Imobilização de Lipase de Candida Antarctica B em quitosana para obtenção de biodiesel por transesterificação do oleo de mamona [Dissertação] Santa Catarina- RS: Universidade Federal de Santa Catarina, Centro Tecnológico; 2007. 107 p.

18. Oliveira RWZ, Vieira IC. Construção e aplicaçãode biossensores usando diferentes procedimentos de imobilização daperoxidase de vegetal em matriz de quitosana; Quim Nova. 2006 Out;29(5):932-939, doi:10.1590/S0100-40422006000500009

19. Oliveira TS de, Cerqueira KS, Pereira ACL, Souza RR de, Silva CF. Isolamento e seleção de microrganismos produtores de enzimas amilolíticas: In: Anais do XXI Congresso Brasileiro de Engenharia Química - COBEQ, 2016. 25-29 Setembro. Fortaleza-CE. ISSN: 21785600

20. Miller GL. Use of dinitrosalicylic acid reagent for determination of reducing sugar. Anal Chem. 1959 Mar;31(3):426-428, doi:10.1021/ac60147a030

21. Tripathi P, Kumari A, Rath P, Kayastha AM. Immobilization of $\alpha$-amylase from mung beans (Vigna radiata) on Amberlite MB 150 and chitosan beads: A comparative study. J Mol Cata B-Enzym. 2007;49:69-74, doi:10.1016/j.molcatb.2007.08.011

22. Kumari A, Kayastha AM. Immobilization of soybean (Glycine max) $\alpha$-amylase onto Chitosan and Amberlite MB-150 beads: Optimization and characterization. J. Mol. Cata. B-Enzym. 2011;69:8-14, doi:10.1016/j.molcatb.2010.12.003

23. Pereira EB, de Castro HF, de Morais FF, Zanin GM. Kinetic studies of lipase from Candida rugosa. A comparative study of the free and the immobilized enzyme onto porous chitosan beads. Biochem Biotechnol. 2001;91-93(1-9):739-752, doi:10.1385/ABAB:91-93:1-9:739 